\title{
International Trade Openness and Inflation in Asia
}

\author{
Yutaka Kurihara \\ Deparment of Economics, Aichi University, Japan \\ E-mail: kurihara@vega.aichi-u.ac.jp
}

Received: January 24, 2013

Accepted: February 14, $2013 \quad$ Online Published: March 7, 2013

doi:10.5430/rwe.v4n1p70

URL: http://dx.doi.org/10.5430/rwe.v4n1p70

\begin{abstract}
This article examines whether international trade openness is related with inflation or not in Asian countries. The relationship in the world has been discussed including economic growth for a long time from both theoretical and empirical ones, however, there has not been any consensus about this problem. It is necessary to analyze this relationship to achieve sound economic growth. Panel data in Asia and OECD countries are used to examine the relationship between international trade openness and inflation empirically in both areas. The results show that the relationship exists both in Asia and in OECD countries, however, it exists strongly in Asian recent period.
\end{abstract}

Keywords: Asia, International trade, Inflation, OECD, Openness

\section{Introduction}

After the World War Second, most countries have expanded international trade while raising inflation rate. Inflation has been one of the most important concerns for policy makers, especially central banks, as it creates uncertainty in the economy that occur adversely economic growth. Maintaining un-inflationary stable economic growth has been the center economic concern for policy makers all over the world.

International trade usually creates economic growth. On the other hand, it also creates inflation. This article examines the relationship between international trade openness and inflation. Increasing openness of the economy can cause unstable prices in domestically, which may lead to an unexpected impact on the country. Considering sound economic growth, it would be necessary to examine carefully the relationship between international trade openness and inflation. In spite of the fact that the relationship has been discussed including economic growth for a long time from both theoretical and empirical views, there has not been any consensus about this problem depending on time span, region, empirical method, and so on.

This article is structured as follows. After this introduction, section 2 reviews related studies from the past. Section 3 provides a theoretical model for empirical analysis. Section 4 shows the results and analyzes them. Finally, this article ends with a brief summary.

\section{The Relationship between International Trade and Inflation}

From the past the relationship between international trade and inflation has been discussion from both theoretical and empirical views. Rogoff (1985) showed that as the economies become more open, they tend to have less inflation. The reason is that such economies obtain less surprise from inflation. Romer (1993) indicated that unanticipated financial expansion causes domestic exchange rate depreciation and the depreciation are larger in more open economies, the benefits of this is a decreasing function of the openness of the economy. Alfaro (2005) also showed that surprise financial expansions by financial authorities bring real exchange rate depreciation. As the economy becomes open, the more the real exchange rate depreciation, they reduce incentives to conduct monetary expansion as inflation goes up.

Recently, Zakaria (2010) indicated that there was a positive relationship between openness of the economy and inflation in Pakistan. Lartey (2012) showed that openness causes sensitive response in non-tradable goods inflation, and that optimal financial policy changes along with the degree of openness. Evans (2012) indicated that inflationary bias of openness was reduced by the degree of imperfect competition in the domestic market. The reason is known "beggar thy neighbor". Kim and Lee (2012) showed that openness of the economy made a large contribution to Korea's economic growth. In a comparison among some indicators of international trade, openness of the economy is more sensitive to growth. 
On the other hand, Triffin and Grudel (1962) indicated that more open economies tended to cause low inflation as cheaper availability of goods that costs much in the domestic country. Iyoha (1973) showed the similar empirical results, however, some variables were not always significant. Romer (1993) found a negative relationship between openness of the economy and inflation for the period 1970s and 1980s even when controlling for the development level of a country, central bank independence, and political stability were keeping. Lane (1997) and Terra (1998) found a negative relationship between openness of the economy and inflation but found the relationship could be reduced by managing economic growth and indebtedness. Cavallari (2001) and Daniels et al. (2006) employed theoretical models in which the labor market of the open economy is characterized by "union-style wage setting behavior" and in which more openness leads to more inflation in countries with intermediate levels of unionization. Daniels et al. (2005) and Badinger (2009) indicated that the effect of openness on inflation is negative by employing sacrifice ratio. Zakaria (2010) found that conversion of domestic currency into foreign currency in open economies was easy, so inflation rate would be low as the economy became open. Hamif and Batool (2006) and Mukhtar (2010) found that openness had a negative impact on domestic price in Pakistan. Wynne and Kersting (2007) found that there was a strong negative relationship between openness of the economy and inflation in the long-run in the United States. Jafari and Samimi et al. (2011) showed that openness had a negative impact on inflation in the short-run, however, had not effect in the long-run in Iran.

Alfaro (2005) found that openness of the economy did not play for reducing inflation. Badinger (2009), which employed Rogoff-style model including Phillips curve, could not find negative relationship between openness of the economies and inflation in OECD countries. Binici and Cheung (2012) showed that openness of the economy could affect inflation through changes in price competitiveness and productivity. Kim et al. (2012) showed that openness and globalization make a large contribution to Korea's economic growth. Manni et al. (2012) showed that international trade liberalization did not seem to have affected inflation in the domestic economy.

Krugman (1990) showed the reason why trade liberalization was good for economic growth in developing countries. Balassa (1978) found that the rate of growth of exports was linked with the rate of growth. Dollar (1992), Edward (1998), Frankel and Romer (1999), Bhagwati and Srinivasan (2001), and Dollar and Kaaray (2001) also showed empirical evidence of the positive effect on economic growth. Recently, Manni et al. (2012) showed that greater openness have had a good effect on economic development.

Kim et al. (2012) showed that international trade caused economic growth in high-income, low-inflation, and nonagricultural countries, but had an unfavorable impact on economic growth in countries with opposite attributes.

Finally, Rodriguez and Rodrik (1999) proposed problems of over-enthusiasm on the questionable outcomes of researches showing strong positive correlation between openness of the economy and growth. Rogers (2003) indicated that investment and growth were closely linked and that hinder investment might reduce economic growth. Gwartney et al. (2006) found that both the ratio of private and public investments to GDP were positively linked with the growth rate.

Svalerd and Vlachos (2002) and Feeney and Hillman (2004) showed that Financial development might lead to greater trade openness if financial institutions provided more adequate insurance and risk diversification. Moreover, Kletzer and Bardhan (1987) and Beck (2002) showed that some mature financial markets constituted a comparative advantage for industrial sector that relied on external financing. Wooldridge (2000) used error correction model to examine the dynamics in the relationship between growth and openness.

This article performs empirical analyses to examine the relationship between international trade and inflation in Asia and OECD. As explained above, however, there is no consensus about it depending on sample period, countries, and empirical methods.

\section{Theoretical Model and Empirical Method}

This article uses panel data and estimates the relationship between openness of the economy and inflation. Considering and analyzing the relationship accurately would be important for attaining sound economic growth. The estimated equation is as follows:

INFLATIONt $=\alpha 1+\alpha 2$ INFLATION(-1)it $+\alpha 3$ OPENNESSit $+\alpha 4$ GDPit + uit

INFLATION is an inflation rate (CPI: consumer price index), OPENNESS is the ratio of trade (volume of export + volume of import to GDP), GDP presents GDP per capita.

The empirical method is GMM and fixed effects The reason is as follows..

One estimation problem in such equations of the kind is the existence of unobservable country specific effects and 
also lagged dependent variables among the explanatory variables. This problem could be overcome by GMM (Generalized Method of Moment) method. This method requires a decision on which variable to use as instrumental variables. In this equation, the lagged values of dependent and explanatory variables are used as instrumental variables.

Fixed effects model is useful in analyzing the impact of variables that vary over time. It explores the relationship between predictor and outcome variables within an entity (in this case, country). Each entity has its own individual characteristics that may or may not influence the predictor variables. When using fixed effect model, it is assumed that something within the individual may impact or bias the predictor or outcome variables and we need to control for this. This is the rationale method for the assumption of the correlation between entity's error term and predictors' variables. Fixed effects model does not remain the effect of those time-invariant characteristics from the predictor variables so it can evaluate the predictors' net effect. However, there is an important assumption of the fixed effects model, which those time-invariant characteristics are unique ones to the individual and should not be correlated with other individual characteristics.

Moreover, random effects model is another candidate to be examined. Random effect models are employed in the analysis of panel or hierarchical data model when one assumes no fixed effects (no individual effects). The fixed effects model is specific one of the random effects model. Hausman test can be used to differentiate between fixed effects model and random effects model in panel data. The test can be performed where the null hypothesis is that the preferred model is random effects versus the alternative (fixed effects).

For these estimations, the number of data sometimes occurs problems. This fact is taken into account and the sample period is extended over a time span 10 years, which is large, the problem of stability is not expected to affect the results, a problem with when the number of observations is small.

Chow test as Yucel (2009) is also employed. The test is most commonly used in time series analysis to test for the presence of a structural break and helps to determine whether the independent variables have different impacts on different subgroups of the linear equation. A significant difference indicates a structural change in the relationship (Kurihara, 2011). This study uses this method and analyses the results.

The countries estimated are Asian countries and OECD countries. Due to the data availability, Indonesia, Malaysia, Philippines, and Thailand are included for Asia. These countries and Vietnam are called ASEAN 5. Comparing these countries is important to analyze the reason of achieving economic growth. Also, the time period is split into two, past one and recent one. The first one is 1990s and the second one is from the 2000s (till 2011). All the data is quarterly and is from International Financial Statistics (IMF).

\section{Empirical Results}

First, Hausman's test is performed which fixed effects model or random effects model is more preferable.

$<$ Insert Table 1 Here $>$

It is clear that fixed effects model is suitable. Compare to random mode, fixed effects model should be selected.

Secondly, the Chow test is performed for choosing between GMM regression and fixed effects model.

$<$ Insert Table 2 Here $>$

The results are almost certain that fixed effects models are appropriate, however, both GMM and fixed effects model are reported in Table $3 \mathrm{a}$ and Table $3 \mathrm{~b}$.

$<$ Insert Table 3a Here $>$

$<$ Insert Table 3b Here $>$

There is not much difference between GMM and fixed effects model. The results show that there is generally a statistically significant correlation between openness of the economy and inflation. The effect in Asia is stronger than the ones in OECD economies. However, the coefficient has decrease from 1990s to 2000s. Inflation has declined around the world for the past two decade. There are only a few countries which show double-digit inflation rates all over the world. Not only OECD but also Asian economies are not exceptions. This situation may have affected the result. However, statistically positive relationship still exists.

The coefficient of INFLATION(-1) is positive and significant. Also, the coefficients of GDP have the expected sign. As mentioned before, the results, especially the relationship between openness of the economy and inflation are ambiguous, however, the results of this study is clear.

For the results of OECD, Japanese situation may have affected. In the 1990s, Japan experienced serious economic and financial crises after the bubble economy burst in the late 1980s. Recorded annual economic growth rates were often negative, and deflation has been prevailing in spite of the fact that policy makers have combated to overcome 
deflation and recession. Table 4 is the result of Japanese case. The empirical method is the same with Table $3 \mathrm{a}$. GMM instead of OLS or other methods is used for estimation.

$<$ Insert Table 4 Here $>$

The results seem interesting. In 1990s, the coefficient of openness of the economy is negative, however, it is not significant. Moreover, the coefficient of GDP is also negative and insignificant. From the middle of the 1980s, Japan experienced 'bubble economy', stock and land prices great rising, and it burst suddenly at the beginning of 1990s. However, the results of OECD are expected as mentioned before in spite of the fact that Japanese situation was unstable. On the contrary, the results of 2000s are stable in Japan and OECD.

\section{Conclusion}

This article examined the relationship between openness of the economy and inflation. The results show that there is generally a statistically significant correlation between openness of the economy and inflation both in 1990s and 2000s. The effect in Asia is stronger than the ones in OECD economies.

There is some room for further study. The openness of the economy is defined as the ratio of trade volume (imports + export) to GDP in this study. Samimi et al. (2012) uses 'KOF' index. Micro-level information is needed for analyzing not onky the relationship between the openness of the economy and inflation but also economic growth. There would be some support to considering economic policy. Expanding countries, regions, and sample period is another problem to be investigated much more in spite of the fact that there is data unavailability. Each country's situation should be included in some cases. Japanese case tells the importance about it. Moreover, if countries seek to enhance international trade while attaining economic growth, they need to conduct some specific policies that facilitate trade. Further study is needed.

\section{Acknowledgements}

I thank the reviewer's valuable comments and suggestions. This work is supported by JSPS KAKENHI.

\section{References}

Alfaro, L. (2005). Inflation, openness, and exchange rate regimes: The quest for short-term commitment. Journal of Development Economics, 77(1), 229-249. http://dx.doi.org/10.1016/j.jdeveco.2004.02.006

Badinger, H. (2009). Globalization, the output-inflation tradeoff and inflation. European Economic Review, 53(8), 888-907. http://dx.doi.org/10.1016/j.euroecorev.2009.03.005

Balassa, B. (1978). Exports and Economic Growth: Is growth export-led or import-led? Journal of Development Economics, 5(2), 181-189. http://dx.doi.org/10.1016/0304-3878(78)90006-8

Beck, T. (2002). Financial development and international trade: Is there a link? Journal of International Economics, 57(1), 107-131. http://dx.doi.org/10.1016/S0022-1996(01)00131-3

Bhagwari, J., \& Srinivasan, T. N. (2001). Trade and poverty in the poor countries. American Economic Review, 92(2), 180-183. http://dx.doi.org/10.1257/000282802320189212

Binici, M., \& Cheung, Y. W. (2012). Trade openness, market competition, and inflation: Some sectoral evidence from OECD countries. International Journal of Finance \& Economics, 17(4), 321-336. http://dx.doi.org/10.1002/ijfe.1451

Cavallari, L. (2001). Inflation and openness with non-atomistic wage setters. Scottish Journal of Political Economy, 48(2), 210-225. http://dx.doi.org/10.1111/1467-9485.00195

Daniels, J. P., Nourzad, F., \& van House, D. D. (2005). Openness, central bank independence, and the sacrifice ratio. Journal of Money, Credit and Banking, 37(2), 371-379. http://dx.doi.org/10.1353/mcb.2005.0020

Daniels, J. P., Nourzad, F., \& van House, D. D. (2006). Openness, centralized wage bargaining, and inflation. European Journal of Political Economy, 2284, 969-988. http://dx.doi.org/10.1016/j.ejpoleco.2005.09.001

Dollar, D. (1992). Outward-oriented development economies really do grow more rapidly: Edidence from 95 LDCs, 1976-1985. Economic Development and Cultural Change, 40(3), 523-544. http://dx.doi.org/10.1086/451959

Dollar, D., \& Kaary, A. (2001). Trade, growth, and poverty. World Bank, Development Research Group, Washington, D.C., USA.

Edwards, S. (1998). Openness, productivity and growth: What do we really know? The Economic Journal, 108(447), 383-398. http://dx.doi.org/10.1111/1468-0297.00293

Evans, R.W. (2012). Is openness inflationary? Policy commitment and imperfect competition. Journal of Macroeconomics, 34(4), 1095-1110. http://dx.doi.org/10.1016/j.jmacro.2012.05.002

Feeney, J., \& Hillman, A. (2004). Trade liberalization through asset markets. Journal of International Economics, 
64(1), 151-167. http://dx.doi.org/10.1016/j.jinteco.2003.06.001

Hanif, M. N., \& Batool, I. (2006). Openness and Inflation: A case study of Pakistan. MPRA Paper, No.10214, University Library of Munich, Germany.

Iyoha, M. A. (1973). Inflation and openness in less developed economies: A cross country analysis. Economic Development and Cultural Change, 22(1), 31-38. http://dx.doi.org/10.1086/450686

Jafari Samimi, A., Ghaderi, S., \& Sanginabadi, B. (2011). Openness and inflation in Iran. International Journal of Economics and Management Engineering, 1(1), 42-49.

Kim, Y. K., \& Lee, J. H. (2012). A sensitivity analysis regarding the impacts of trade openness and globalization growth: empirical evidence from Korea. Journal of International Logistics and Trade, 10(2), 47-50.

Kim, Y. K., Lin, S. C., \& Suen, Y. B. (2012). The simultaneous evolution of economic growth, financial development, and trade openness. The Journal of International Trade \& Economic Development, 21(4), 513-537. http://dx.doi.org/10.1080/09638199.2010.497933

Kletzer, K., \& Bardhan, P. K. (1987). Credit markets and patterns of international trade. Journal of Development Economics, 27(1-2), 57-70. http://dx.doi.org/10.1016/0304-3878(87)90006-X

Krugman, P. R. (1990). Rethinking International Trade. Massachusetts: The MIT Press, USA.

Kurihara, Y. (2012). Exchange rate determination and structural changes in response to monetary policies. Studies in Economics and Finance, 29(3), 187-196. http://dx.doi.org/10.1108/10867371211246858

Lane, P. R. (1997). Inflation in open economies. Journal of International Economics, 42(3-4), 327-347. http://dx.doi.org/10.1016/S0022-1996(96)01442-0

Lartey, E. (2012). Financial openness, nontradable inflation and optimal monetary policy. Economics Letters, 117(3), 782-785. http://dx.doi.org/10.1016/j.econlet.2012.08.043

Manni, U. H., Siddiqui, S. A., \& Afzai, M. N. I. (2012). An empirical investigation on trade openness and economic growth in Bangladesh economy. Asian Social Science, 8(11), 154-159.

Mukhtar, T. (2010). Does trade openness reduce inflation? Empirical evidence from Pakistan. The Lahore Journal of Economics, 15(2), 35-50.

Rodriguez, F., \& Rodrik, D. (1999). Trade policy and economic growth: A skeptic's guide to cross-national evidence. National Bureau of Economic Research, Inc Working paper, 7081.

Rogers, M. (2003). A survey of economic growth. Economic Record, 79(4), 112-135. http://dx.doi.org/10.1111/1475-4932.00082

Rogoff, K. (1985). Can international monetary policy cooperation be counterproductive? Journal of International Economics, 18(1), 199-217. http://dx.doi.org/10.1016/0022-1996(85)90052-2

Romer, D. (1993). Openness and inflation: theory and evidence. Quarterly Journal of Economics, 108(4), 869-903. http://dx.doi.org/10.2307/2118453

Svaleryd, H., \& Vlachos, J. (2002). Markets for risk and openness to trade: How are they related? Journal of International Economics, 57(2), 369-395. http://dx.doi.org/10.1016/S0022-1996(01)00153-2

Terra, C. T. (1998). Openness and inflation: A new assessment. Quarterly Journal of Economics, 113(2), 641-648. http://dx.doi.org/10.1162/003355398555603

Triffin, R., \& Grubel, H. (1962). The adjustment mechanism to differential rates of monetary expansion among the countries of the European economic community. The Review of Economics and Statistics, 44(4), 486-491. http://dx.doi.org/10.2307/1926668

Wooldridge, J. M. (2000). Introductory Econometrics: A modern approach. South-Western College Publishing, USA.

Wynne, M. A., \& Kersting, E. K. (2007). Openness and inflation. Staff papers, Federal Reserve Bank of Dallas, No. 2.

Yanikkaya, H. (2000). Trade openness and economic growth: A cross-country empirical investigation. Journal of Development Economics, 72(1), 57-89. http://dx.doi.org/10.1016/S0304-3878(03)00068-3

Yucel, F. (2009). Causal relationship between financial development, trade openness and economic growth: The case of Turkey. Journal of Social Sciences, 5(1), 33-42. http://dx.doi.org/10.3844/jssp.2009.33.42

Zakaria, M. (2010). Openness and inflation: evidence from the time series data. Dogus Universitesi Dergisi, 11(2), 313-322. 
Table 1. Hausman test

\begin{tabular}{ccccc}
\hline & \multicolumn{2}{c}{$1990-1999$} & \multicolumn{2}{c}{$2000-2011$} \\
\cline { 2 - 5 } & Asia & OECD & Asia & OECD \\
\hline Chi-squared & 59.121 & 24.680 & 25.845 & 31.683 \\
p-value & 0.000 & 0.002 & 0.003 & 0.000 \\
\hline
\end{tabular}

Table 2. Chow test

\begin{tabular}{ccccc}
\hline & \multicolumn{2}{c}{$1990-1999$} & \multicolumn{2}{c}{$2000-2011$} \\
\cline { 2 - 5 } & Asia & OECD & Asia & OECD \\
\hline F-value & 8.012 & 35.326 & 79.480 & 92.439 \\
p-value & 0.010 & 0.001 & 0.000 & 0.000 \\
\hline
\end{tabular}

Table 3a. Results of empirical analysis: GMM

\begin{tabular}{ccccc}
\hline & \multicolumn{2}{c}{$1990-1999$} & \multicolumn{2}{c}{$2000-2010$} \\
\cline { 2 - 5 } & Asia & OECD & Asia & OECD \\
\hline Openness & 0.279 & 0.040 & 0.082 & 0.070 \\
& $(0.000)$ & $(0.002)$ & $(0.001)$ & $(0.002)$ \\
INF(-1) & 0.059 & 0.619 & 0.208 & 0.090 \\
GDP & $(0.002)$ & $(0.000)$ & $(0.005)$ & $(0.032)$ \\
& -0.003 & -0.0008 & -0.0007 & -0.0000009 \\
Constant & $(0.001)$ & $(0.002)$ & $(0.001)$ & $(0.044)$ \\
& 22.678 & 25.034 & 39.331 & 2.282 \\
F-value & $(0.000)$ & $(0.000)$ & $(0.000)$ & $(0.070)$ \\
Adj.R ${ }^{2}$ & 45.088 & 29.150 & 6.885 & 14.762 \\
\hline
\end{tabular}

Note) Parentheses are $\mathrm{p}$ values.

Table 3b. Results of empirical analysis: Fixed effects

\begin{tabular}{ccccc}
\hline & \multicolumn{2}{c}{$1990-1999$} & \multicolumn{2}{c}{$2000-2010$} \\
\cline { 2 - 5 } & Asia & OECD & Asia & OECD \\
\hline Openness & 0.324 & 0.041 & 0.075 & $(0.000)$ \\
INF(-1) & $(0.002)$ & $(0.002)$ & 0.271 & $(0.000)$ \\
& 0.044 & 0.619 & $(0.000)$ & 0.105 \\
GDP & $(0.002)$ & $(0.001)$ & -0.0006 & $(0.034)$ \\
& -0.004 & -0.0003 & $(0.007)$ & -0.0000009 \\
Constant & $(0.002)$ & $(0.005)$ & 39.892 & $(0.095)$ \\
& 21.686 & 25.123 & $(0.000)$ & 1.721 \\
F-value & $(0.000)$ & $(0.000)$ & 4.926 & $(0.181)$ \\
Adj.R ${ }^{2}$ & 45.129 & 34.878 & 0.335 & 6.521 \\
\hline
\end{tabular}

Note) Parentheses are $\mathrm{p}$ values.

Table 4. Results of empirical analysis: Japan (GMM)

\begin{tabular}{ccc} 
& $1990-1999$ & $2000-2011$ \\
\cline { 2 - 3 } Openness & $-6.36 \mathrm{E}-07$ & 0.000632 \\
& $(0.993)$ & $(0.000)$ \\
INF(-1) & 0.617518 & 0.643823 \\
GDP & $(0.000)$ & $(0.000)$ \\
& $-1.88 \mathrm{E}-07$ & $1.32 \mathrm{E}-07$ \\
Constant & $(0.009)$ & $(0.001)$ \\
& 0.097126 & -0.091108 \\
F-value & $(0.002)$ & $(0.000)$ \\
Adj.R & 27.10020 & 46.17919 \\
\end{tabular}

Note) Parentheses are $\mathrm{p}$ values. 